\title{
The Effects of Cathode Parameters on the Performance of Poly(2,5-Benzimidazole)-Based Polymer Electrolyte Membrane Fuel Cell
}

\author{
T Maiyalagan · S Pasupathi · B G Pollet
}

(C) Springer Science+Business Media New York 2014

\begin{abstract}
The effects of electrode parameters on membrane electrode assembly performance including Pt loading, hydrophobicity during heat treatment, catalyst layer thickness and the amount of polytetrafluoroethylene (PTFE) in the cathode are investigated. The fuel cell performance is maximized via catalyst utilization by optimizing the phosphoric acid content in the electrodes. Heat treatment of gas diffusion electrode results in an increase in hydrophobicity and a decrease in phosphoric acid content in the catalyst layer, which drastically affects the fuel cell performance. In our conditions, a maximum fuel cell performance of $270 \mathrm{~mW} \mathrm{~cm}^{-2}$ was achieved at $160{ }^{\circ} \mathrm{C}$ with air using $1 \mathrm{mg} \mathrm{Pt} \mathrm{cm}{ }^{-2}$ total catalyst loading (20\% PTFE). The fuel cell performance and the poisoning effect of carbon monoxide in poly(2,5-benzimidazole) (ABPBI)-membrane-based high-temperature membrane electrode assemblies were investigated with respect to carbon monoxide concentrations. Fuel cell performance of Pt alloys $(\mathrm{Pt}-\mathrm{Cu} / \mathrm{C}, \mathrm{Pt}-\mathrm{Fe} / \mathrm{C}, \mathrm{Pt}-\mathrm{Ni} / \mathrm{C}$ ) is compared with that of $\mathrm{Pt} / \mathrm{C}$ at temperatures between 140 and $180^{\circ} \mathrm{C}$. It was observed that $\mathrm{Pt}-\mathrm{Cu} / \mathrm{C}$ alloy catalysts exhibit higher performance with lower catalyst loadings $\left(0.4 \mathrm{mg} \mathrm{Pt} \mathrm{cm}{ }^{-2}\right)$ than $\mathrm{Pt} / \mathrm{C}$ catalyst. The performance of alloy catalysts follows the order of $\mathrm{Pt}-\mathrm{Cu} / \mathrm{C}>$ $\mathrm{Pt}-\mathrm{Fe} / \mathrm{C}>\mathrm{Pt}-\mathrm{Ni} / \mathrm{C}>\mathrm{Pt} / \mathrm{C}$.
\end{abstract}

Keywords Gas diffusion electrode - HT-PEMFCs · ABPBI · Phosphoric acid $\cdot$ Membrane electrode assembly $\cdot$ Pt alloy catalysts $\cdot$ Electrode performance

T. Maiyalagan $(\bowtie) \cdot$ S. Pasupathi $\cdot$ B. G. Pollet HySA Systems Competence Centre, South African Institute for Advanced Materials Chemistry, University of the Western Cape, Modderdam Road, Bellville, Cape Town 7535, South Africa e-mail: maiyalagan@gmail.com

\section{Introduction}

The progress of high-temperature polymer electrolyte membrane fuel cells (HT-PEMFCs) in recent years attracted increased attention as an alternative to conventional lowtemperature PEM fuel cells [1]. Nafion ${ }^{\circledR}$ is the accepted current bench mark perfluorosulphonic acid polymer membrane used in low-temperature fuel cells [2]. The lack of mass commercialization of low-temperature PEM fuel cell is due to limited operation temperature $\left(<100{ }^{\circ} \mathrm{C}\right)$, fuel crossover, cost (catalyst and Nafion ${ }^{\circledR}$ membrane) and durability [3]. HTPEMFCs run in the temperature range between 120 and $200{ }^{\circ} \mathrm{C}$ and give numerous advantages compared to lowtemperature polymer electrolyte membrane fuel cells (LTPEMFCs), for example, high CO tolerance, elimination for humidification of reactant gases and simplified heat and water management of the fuel cell system. HT-PEMFCs offer the reduction of significant system components such as gas purification and humidification. The waste heat from HT-PEM fuel cell $\left(\sim 160{ }^{\circ} \mathrm{C}\right)$ is very usable and ideally suited for combined heat and power (CHP) applications than LT-PEM fuel cell $\left(\sim 70^{\circ} \mathrm{C}\right)[4,5]$. Fuel cell powered micro-CHP systems are viable for commercialization. For example, Japan has already installed nearly 3000 micro-CHP fuel cell systems, albeit based on LT-PEMFC, under the trade name ENEFARM.

The performance of HT-PEMFC membrane electrode assemblies (MEAs) strongly depends on phosphoric acid content in the PBI [poly (2,2'-(m-phenylene)-5, 5'bibenzimidazole)] electrolyte [6]. However, chemically related structure such as poly(2,5-benzimidazole) (ABPBI) membranes have been used as a promising alternative for hightemperature PEM fuel cells and exhibited comparable performance to PBI membranes [6-10]. ABPBI membrane has low cost, good mechanical strength, high phosphoric acid uptake as compared to PBI membranes [10, 11]. HT-PEMFC MEAs 
based on $\mathrm{PBI} / \mathrm{ABPBI} /$ other membranes saturated with phosphoric acid became commercially available under different trade name such as Celtec (BASF) and Advent $[12,13]$.

The gas diffusion electrodes (GDE) form an integral part of the membrane electrode assembly, consist of gas diffusion layer (GDL) and catalyst layer each performing a specific function. The GDL is preferably a carbon paper or a carbon cloth offering a supporting structure for the catalyst layer and also acting as a passage for fuel and oxygen gas to the catalyst. Great interest has been paid in the past, and excellent reviews have been published on gas diffusion electrodes for lowtemperature fuel cells [14]. Polytetrafluoroethylene (PTFE) binder is highly hydrophobic, and the usage of PTFE binder in gas diffusion electrode increases the porous structure in the catalyst layer and increases mass transport of the reactants. The influence of different types of GDE and the amount of PTFE used on fuel cell performances have been well studied [15]. Lobato et al. [16] studied the effect of PTFE loading in the GDL on PBI-based PEM fuel cell. To maximize the performance and stability of ABPBI MEAs, it is necessary to maintain the phosphoric acid distribution between the membranes, the catalyst layers and the gas diffusion layers. Wannek et al. [17] reported the relation between the phosphoric acid content in the catalyst layer and fuel cell performance. The fuel cell performances of the ABPBI MEAs depend on many electrode parameters: (1) type of gas diffusion layer and its characteristics (porosity and thickness), (2) PTFE amount, (3) phosphoric acid amount, (4) heat treatment of gas diffusion electrode, (5) thickness of catalyst layers and (6) nature of electrocatalyst (Pt and Pt alloys, Pt loading, Pt particles size, type of carbon as the support).

There are a lot of scientific efforts that are under way to reduce Pt loading and improve the catalytic activity of the cathode. Pt alloy catalysts, including Pt-Co, Pt-Ni and PTFE exhibit higher ORR activity than $\mathrm{Pt} / \mathrm{C}$, have been thoroughly investigated for low-temperature PEM fuel cells. Although Pt alloys exhibit higher ORR activity, there are no much studies on the performance of Pt alloys in ABPBI-based high-temperature fuel cells. Also, there is the possibility of dissolution of metal in the phosphoric environment. Thus, high performance and reduction in Pt loading of ABPBI MEAs can be achieved using suitable alloy catalyts.

The purpose of the present study is to identify proper active Pt alloy catalysts with reduced precious loading that lead to improved ORR activity and anode catalyst activity for the oxidation of $\mathrm{CO}$ in the presence of hydrogen in ABPBIbased high-temperature fuel cells. One of the appealing greatest advantages of high-temperature PEM fuel cells is the tolerance of anodes for the oxidation of $\mathrm{CO}$ in the presence of hydrogen. Additionally, the commercialization of MEAs and fuel cells made thereof, using the new membrane materials and optimized electrode structure of high-performance fuel cells for commercialization, still requires considerable research and development efforts. The aim of this study is to improve the performance and reduce the loading of ABPBIbased MEAs by optimizing the electrode parameters. The fabricated MEAs were tested in laboratory scale $25 \mathrm{~cm}^{2}$ cells at $160{ }^{\circ} \mathrm{C}$ to evaluate the most promising MEA formulation. The catalyst and electrode structure in the MEAs play a major role in determining fuel cell performance. This paper explores the effects of electrode parameters such as $\mathrm{Pt}$ loading, catalyst thickness, PTFE content and carbon supports on the performance of the cathode for ABPBI-based HTPEMFC. Besides, the electrochemical performance in the presence of various concentrations of carbon monoxide is discussed.

\section{Experimental Procedures}

Physiochemical Characterization of the Catalysts

The commercial catalysts used in the MEAs were analyzed by the X-ray diffraction (XRD) technique, which was recorded in the range of $10-80^{\circ}$ with a scan step width of 0.02 and a counting time of $1 \mathrm{~s}$ per step using Bruker D2 X-ray diffractometer with $\mathrm{Cu} \mathrm{K} \alpha$ radiation $(\lambda=1.5418 \AA)$. Nitrogen adsorption-desorption isotherms of the catalysts samples were obtained using a Micromeritics ASAP 2020 sorptometer. The total surface area and pore volume were calculated using the Brunauer-Emmett-Teller (BET) and the multi-point method.

\section{MEA Preparation}

The ABPBI membranes were purchased from FuMA-Tech in an acid-free form. The dry ABPBI membranes (previously cut into $7 \times 7 \mathrm{~cm}$ ) were immersed in phosphoric acid solutions $(85 \%)$ and then heated at $120^{\circ} \mathrm{C}$ for $12 \mathrm{~h}$ for effective doping of phosphoric acid across the polymer. The excess phosphoric acid was removed from the ABPBI membrane.

The protonic conductivity of ABPBI membrane without a dopant is negligible and phosphoric acid has the highest intrinsic proton conduction among the substances known. Higher doping of phosphoric acid in ABPBI membranes facilitates higher proton conduction. However, the mechanical stability deteriorates and ABPBI membranes disintegrate on increasing the doping level of phosphoric acid at higher temperatures. In our study, the ABPBI membrane was treated in $85 \%$ (or $14.8 \mathrm{M}$ ) phosphoric acid at $120{ }^{\circ} \mathrm{C}$ for $12 \mathrm{~h}$. The treated membrane contained 3.1 molecules of phosphoric acid per repeat unit [18]. The specific conductivity for ABPBI $\times 3.1$ $\mathrm{H}_{3} \mathrm{PO}_{4}$ at $140{ }^{\circ} \mathrm{C}$ has found to be $74 \mathrm{mS} \mathrm{cm}^{-1}[17,18]$.

The phosphoric acid doped ABPBI membrane samples were placed in-between catalyzed GDEs to form the MEAs. Catalyst inks were coated on the commercial gas diffusion layer (GDL, carbon paper) (H2315 CX196) obtained from 
Freudenberg FCCT, Germany. Catalyst inks were prepared with mixture of appropriate amount of platinum loading of 20 to $60 \mathrm{wt} \%$ (JM HiSPEC 4000, from Johnson Matthey) and aqueous dispersions of PTFE (Dyneon) were prepared by ultrasonic $(40 \mathrm{kHz})$ agitation for $20-40 \mathrm{~min}$ in a mixture of water and isopropanol. The catalyst ink was highly dispersed by an ultrasonic homogenizer several times for $30 \mathrm{~s}$ each. This catalyst ink was agitated until it turned into good dispersion. These inks were uniformly sprayed on the microporous layer of a commercially available GDL (Freudenberg FCCT) by a spraying technique followed by an air drying step. The GDE were produced with controlled platinum loadings ranging between 0.5 and $2.0 \mathrm{mg} \mathrm{Pt} \mathrm{cm}{ }^{-2}$. The catalyst layers were impregnated with appropriate amounts of phosphoric acid to the surface of the GDEs and were left overnight for uniform distribution. The phosphoric acid impregnated gas diffusion electrode is then combined with phosphoric acid doped ABPBI membranes to form an MEA.

\section{Single Fuel Cell Tests}

The fuel cell tests for evaluating the HT-PEMFC were conducted in $25-\mathrm{cm}^{2}$ single cell setups using graphite flow field plates. Commercial Freudenberg gaskets made of fluorinated polymer with thickness of $50 \mu \mathrm{m}$ were used as sealants. The cell was assembled in a cell compression unit from Pragma Industries for uniform pressure on the MEA. The MEAs were fabricated with phosphoric acid with doped ABPBI membrane sandwiched GDEs into the test cells without hot pressing. The prepared MEAs were assembled in the cell compression unit (CCU) which operated, at constant force, with high accuracy and was able to precisely measure the influence of compression over the MEA and the GDL. A compression force of $1.5 \mathrm{~N} / \mathrm{mm}^{2}$ was applied throughout all the experiments. The performance of the MEAs was analyzed after conditioning for $24 \mathrm{~h}$ at $+0.6 \mathrm{~V}$ where the cell is operated at $160{ }^{\circ} \mathrm{C}$, with the air and hydrogen using an in-house built up fuel cell test system. The fuel cell test system consists of control of the electronic load Hocherl \& Hackl GmBH load and the mass flow controllers with lab view. Unless otherwise noted, the cells are operated at $160{ }^{\circ} \mathrm{C}$ in ambient pressure using hydrogen and air with stoichiometries of 0.6 and 1.8, respectively.

\section{Results and Discussion}

Physicochemical Characterization of Electrocatalysts

The catalysts surface areas were studied by nitrogen physisorption method that are shown in Figure 1 and the results are summarized in Table 1. The data shows that BET

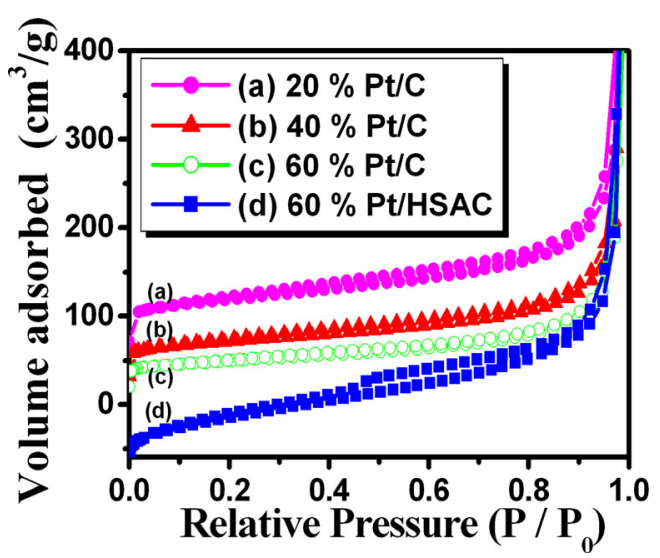

Fig 1 Nitrogen physisorption isotherms of (a) $20 \% \mathrm{Pt} / \mathrm{C}$, (b) $40 \% \mathrm{Pt} / \mathrm{C}$, (c) $60 \% \mathrm{Pt} / \mathrm{C}$ and (d) $60 \% \mathrm{Pt} / \mathrm{HSAC}$ catalysts

surface areas of the catalysts tend to decrease with increase in metal loading on the carbon support. [19] The catalyst $60 \%$ $\mathrm{Pt} / \mathrm{C}$ has a lower surface area and total pore volume than the $40 \% \mathrm{Pt} / \mathrm{C}$ and $20 \% \mathrm{Pt} / \mathrm{C}$. The $60 \% \mathrm{Pt} /$ high surface area carbon (HSAC) has higher surface area compared to 20, 40 and $60 \% \mathrm{Pt} / \mathrm{C}$ due to replacement of conventional Vulcan carbon by high surface area carbon catalyst support. The average Pt particle size of $60 \% \mathrm{Pt} / \mathrm{HSAC}$ catalyst is $3.5 \mathrm{~nm}$ which is smaller than those for other commercial $60 \% \mathrm{Pt} / \mathrm{C}$ catalysts. It was also inferred that metal dispersion is increased by high surface area carbon support.

The BET surface area, total pore volume, micropore volume and pore size distribution of $\mathrm{Pt} / \mathrm{C}$ catalysts vary with Pt loading as shown in Table 1. Pore size distribution data were calculated by the Barrett-Joyner-Halenda (BJH) from the adsorption and desorption branches. The BJH pore size distribution for the commercial electrocatalysts is shown in Figure 2. The catalysts with lower metal loading $(20 \% \mathrm{Pt} / \mathrm{C})$ have usually larger total pore volumes due to higher proportion of micropores on the catalysts. In particular, the decrease of the micropore volume and micropore area was more significant with increasing catalyst loading on the carbon supports. Sixty percent Pt/HSAC has higher content of micro-porosity than 20, 40 and $60 \% \mathrm{Pt} / \mathrm{C}$ catalysts which strongly indicate that $\mathrm{Pt}$ was mainly distributed throughout the microporous structure. The XRD patterns for all commercial catalysts are shown in Figure 3. The characteristic diffraction peaks of the face-centred cubic structure are clearly detected in all the catalyst. However, the intensity and width of the peaks, which are related with the Pt crystallite size, depend upon the carbon material used as support. Pt crystallite sizes obtained from the 220 peak in the XRD diffractograms (shown in Figure 3) using the Scherrer equation are shown in Table 1. It can be clearly seen that the higher the platinum percentage in the catalysts, the larger the platinum particle size resulting in lower platinum surface area [19]. 
Table 1 The results of $\mathrm{N}_{2}$ physisorption on various Pt/C catalysts with same Pt loading $\left(1 \mathrm{mg} \mathrm{Pt} \mathrm{cm}{ }^{-2}\right)$ and $40 \%$ PTFE used in this work

\begin{tabular}{lllllll}
\hline Catalysts & $\begin{array}{l}\text { Particle } \\
\text { size } \\
(\mathrm{nm})\end{array}$ & $\begin{array}{l}\text { BET surface } \\
\text { area } \\
\left(\mathrm{m}^{2} \mathrm{~g}^{-1}\right)\end{array}$ & $\begin{array}{l}\text { Total pore } \\
\text { volume } \\
\left(\mathrm{cm}^{3} \mathrm{~g}^{-1}\right)\end{array}$ & $\begin{array}{l}\text { Micropore } \\
\text { area } \\
\left(\mathrm{m}^{2} \mathrm{~g}^{-1}\right)\end{array}$ & $\begin{array}{l}\text { Micropore } \\
\text { volume } \\
\left(\mathrm{cm}^{3} \mathrm{~g}^{-1}\right)\end{array}$ & $\begin{array}{l}\text { Current density } \\
\left(\mathrm{mA} \mathrm{cm} \mathrm{cm}^{-2}\right) \text { at cell } \\
\text { voltage of } 0.3 \mathrm{~V}^{\mathrm{b}}\end{array}$ \\
\hline $20 \%$ Pt/C (JM HiSPEC 3000) & 2.8 & 184 & 0.822 & 42.39 & 0.018 & 700 \\
$40 \%$ Pt/C (JM HiSPEC 4000) & 3.59 & 141 & 0.65 & 32.34 & 0.014 & 945 \\
$60 \%$ Pt/C (JM HiSPEC 9000) & 5.4 & 101 & 0.704 & 32.0 & 0.011 & 1061 \\
$60 \%$ Pt/HSAC (JM HiSPEC 9100) & 3.5 & 321 & 1.229 & 63.4 & 0.031 & 677 \\
\hline
\end{tabular}

${ }^{\text {a }}$ Estimated from XRD

${ }^{\mathrm{b}}$ Current density of HT-PEMFC single cells measured at $+0.3 \mathrm{~V}$ and $160{ }^{\circ} \mathrm{C}$

Electrode Performance with Variable PTFE Content

The influence of polytetrafluoroethylene (PTFE) content used on fuel cell performances has been previously studied $[20,21]$. The anode and cathode consisted of $40 \mathrm{wt} \% \mathrm{Pt} / \mathrm{C}$

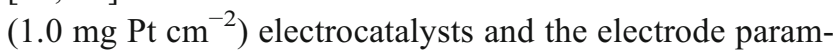
eters of the anode were fixed. PTFE content in the fuel cell catalyst layer plays a major role in the performance of HTPEMFCs. The amount of phosphoric acid in the GDE was kept constant $\left(20 \mathrm{mg} \mathrm{cm}^{-2}\right)$ for the anode and cathode. Typically, 20-60 wt\% PTFE is added to the cathode catalyst layer in phosphoric acid doped ABPBI membrane fuel cells. Heat treatment of PTFE increases the pore volume of the porous structure and facilitates mass transport of the reactants [20, 21]. However, excess PTFE forms a thick catalyst layer that will lead to increased resistance. The fuel cell performance at $160{ }^{\circ} \mathrm{C}$ with varying PTFE contents in cathode catalyst layer is shown in Figure 4. The PTFE content in the cathode catalyst layer was varied up to $60 \mathrm{wt} \%$. A clear trend that increasing the PTFE content decreases the fuel cell performance can be observed in Figure 4. Electrodes with PTFE loading of $20 \mathrm{wt} \%$ in GDEs show higher fuel cell performances. The MEAs with $60 \%$ PTFE content show relatively lower fuel cell performance.

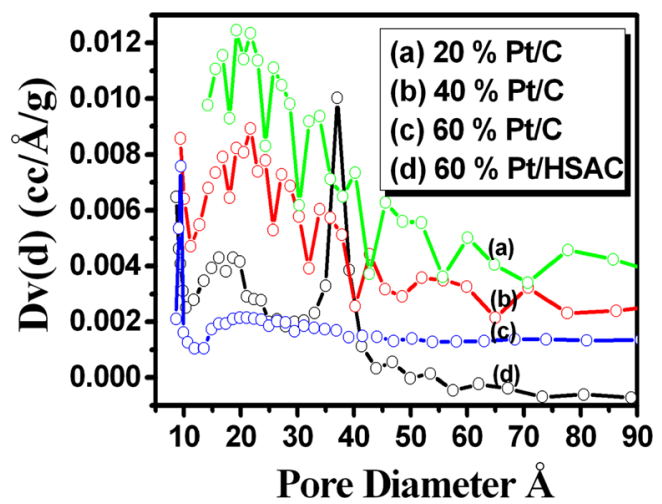

Fig 2 Pore size distribution curves of (a) $20 \% \mathrm{Pt} / \mathrm{C}$, (b) $40 \% \mathrm{Pt} / \mathrm{C}$, (c) $60 \% \mathrm{Pt} / \mathrm{C}$ and $(d) 60 \% \mathrm{Pt} / \mathrm{HSAC}$ catalysts
Electrode Performance with Cathode Catalyst Loading

High-temperature ABPBI PEM MEAs doped with phosphoric acid require relatively higher catalyst loadings compared to low-temperature MEAs. This is due to poor solubility and diffusivity of oxygen in phosphoric acid solutions [22]. Chin et al. observed that the solubility of oxygen decreases exponentially with increasing concentration of $\mathrm{H}_{3} \mathrm{PO}_{4}$ [23]. The rate of mass transport of dissolved oxygen to an electrode is proportional to the product of the diffusivity and the solubility [22]. The effect of platinum loading $(0.5,1$ and

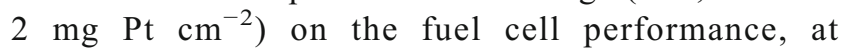
$160{ }^{\circ} \mathrm{C}$ using air as an oxidant, is shown in Figure 5. The anodes used were made of $40 \% \mathrm{Pt} / \mathrm{C}$ with a catalyst loading of $1 \mathrm{mg} \mathrm{Pt} \mathrm{cm}^{-2}$ impregnated with $20 \mathrm{mg} \mathrm{cm}{ }^{-2}$ phosphoric acid as proton conductor. The PTFE binder was kept constant for all the electrodes. Open circuit voltages (OCVs) were more than $+0.9 \mathrm{~V}$ and increased slightly with the increase in platinum loading. It was found that the change in catalyst loadings from 0.5 to $1 \mathrm{mg} \mathrm{Pt} \mathrm{cm}{ }^{-2}$ affects and increases the fuel cell performance.

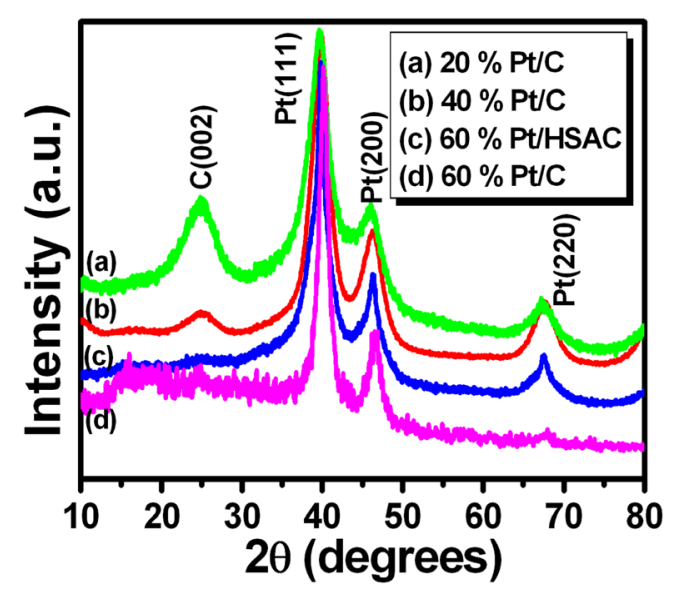

Fig 3 XRD patterns of various percentage of platinum supported carbon catalysts 


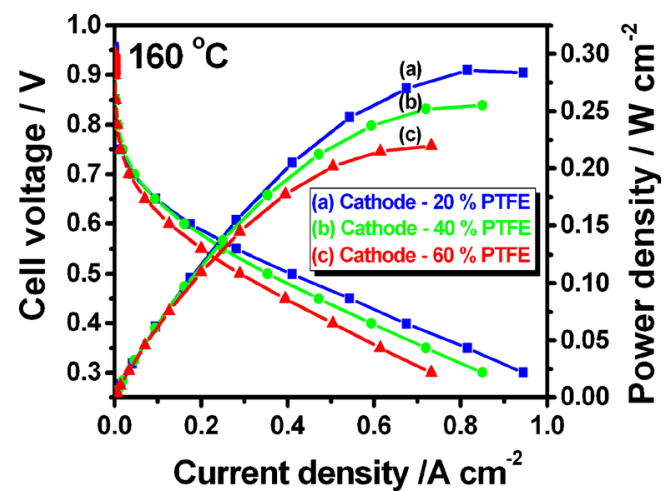

Fig 4 Fuel cell performance of electrodes with different amount of PTFE contents in $40 \% \mathrm{Pt} / \mathrm{C}$ cathode catalyst $\left(1.0 \mathrm{mg} \mathrm{Pt} \mathrm{cm}{ }^{-2}, 20 \mathrm{mg} \mathrm{H}_{3} \mathrm{PO}_{4}\right.$ $\mathrm{cm}^{-2}$ per electrode)

\section{Electrode Performance on the Heat Treatment of GDE}

Heat treatments affect the hydrophobic properties in the GDE. Here, the GDE was dried in air in two steps at $120^{\circ} \mathrm{C}$ for $1 \mathrm{~h}$ and at $230{ }^{\circ} \mathrm{C}$ for $30 \mathrm{~min}$, and then finally heat treated at $350{ }^{\circ} \mathrm{C}$ for 15 min under an inert atmosphere. The electrodes were prepared with $40 \% \mathrm{Pt} / \mathrm{C}$ (anode $1 \mathrm{mg} \mathrm{Pt} \mathrm{cm}{ }^{-2}$, cathode $1 \mathrm{mg} \mathrm{Pt} \mathrm{cm}{ }^{-2}$ ) heat treated GDE and GDE boiled in conc. $\mathrm{H}_{3} \mathrm{PO}_{4}$ at $180^{\circ} \mathrm{C}$ for $12 \mathrm{~h}$. The fuel cell performance measured at $160{ }^{\circ} \mathrm{C}$, with heat treated and untreated electrodes with the same catalyst loading and PTFE contents as shown in Figure 6. Heat treatment of GDE decreases fuel cell performance due to increase in hydrophobicity which significantly reduces the phosphoric content in the cathode. The low content of phosphoric acid in the electrode affects the proton mobility which in turn significantly affects the fuel cell performance.

Influence of the Platinum Loading on Carbon in the Cathode Catalysts on Fuel Cell Performance

The Pt to carbon (Pt/C) weight ratio and the catalyst layer thickness of the electrode determines the platinum utilization and thereby the fuel cell performance. At $160{ }^{\circ} \mathrm{C}$ with air

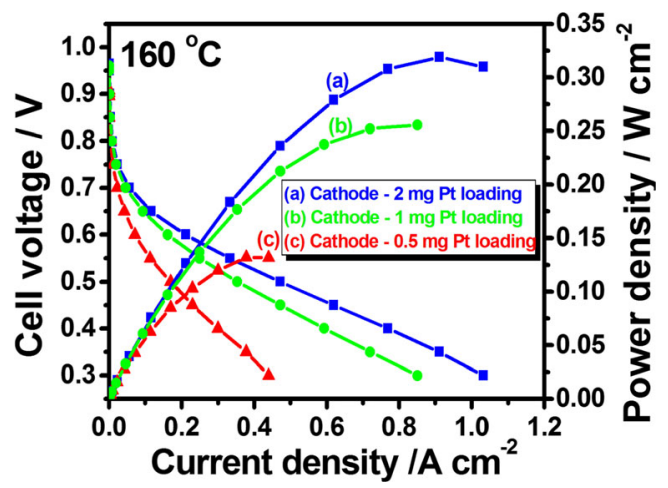

Fig 5 Fuel cell performance of ABPBI-based MEAs with GDEs of the same composition $\left(40 \% \mathrm{Pt} / \mathrm{C}, 40 \%\right.$ PTFE, $20 \mathrm{mg} \mathrm{H}_{3} \mathrm{PO}_{4} \mathrm{~cm}^{-2}$ per electrode) but different cathode catalyst loadings

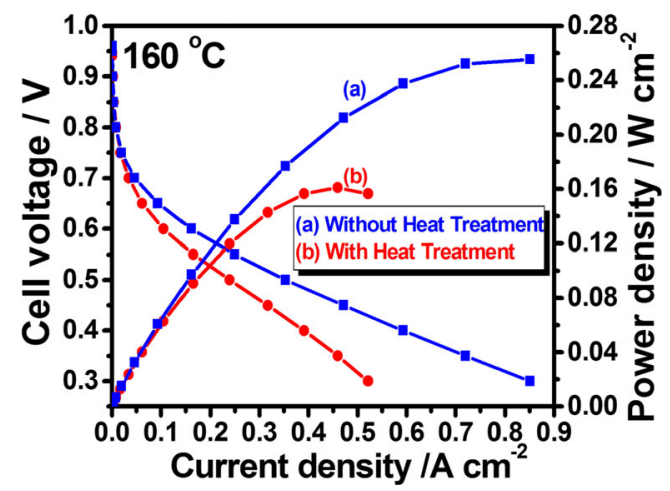

Fig 6 Fuel cell performance of ABPBI-based MEAs with GDEs of the same composition $\left(40 \% \mathrm{Pt} / \mathrm{C}, 1.0 \mathrm{mg} \mathrm{Pt} \mathrm{cm}{ }^{-2}, 40 \%\right.$ PTFE, $20 \mathrm{mg} \mathrm{H}_{3} \mathrm{PO}_{4} \mathrm{~cm}^{-2}$ per electrode) with and without heat treatment

operation, the $60 \% \mathrm{Pt} / \mathrm{C}$ catalyst gave the best fuel cell performance and the MEA with $20 \% \mathrm{Pt} / \mathrm{C}$ showed the lowest fuel cell performance (Figure. 7). This could be due to the fact that $20 \% \mathrm{Pt} / \mathrm{C}$ had smaller XRD crystalline sizes and larger surface areas than the $40 \% \mathrm{Pt} / \mathrm{C}$ and $60 \% \mathrm{Pt} / \mathrm{C}$ catalysts (Table 1-the MEA with $20 \% \mathrm{Pt} / \mathrm{C}$ shows lowest fuel cell performance and $60 \% \mathrm{Pt} / \mathrm{C}$ catalysts are usually good cathode catalysts for ABPBI-based HT-PEMFCs). This may be due to the thinner catalyst layer that facilitates mass transport and better catalyst area utilization [17]. Mostly, catalysts layer thickness is assumed to be proportional to carbon loading. The carbon loading for each electrode was $4,1.5$ and $0.66 \mathrm{mg} /$ $\mathrm{cm}^{2}$ for 20,40 and $60 \% \mathrm{Pt} / \mathrm{C}$, respectively. The BET surface areas and pore volumes of the 20 and $60 \% \mathrm{Pt} / \mathrm{C}$ catalysts are summarized in Table 1. As expected, the increase in metal loading decreases the surface area and pore volume of the catalyst. Sixty percent $\mathrm{Pt} / \mathrm{C}$ has a lower surface area and pore volume than $20 \% \mathrm{Pt} / \mathrm{C}$ catalyst due to the incorporation of the Pt particles into the carbon support that mainly block the micropores of the support. At $1 \mathrm{mg} \mathrm{Pt} \mathrm{cm}{ }^{-2}$ catalyst loading of 140,160 and $180{ }^{\circ} \mathrm{C}$, with air operation, the $60 \% \mathrm{Pt} / \mathrm{C}$ catalyst gave the best fuel cell performance, and the $20 \% \mathrm{Pt} / \mathrm{C}$ exhibited the lowest fuel cell performance.

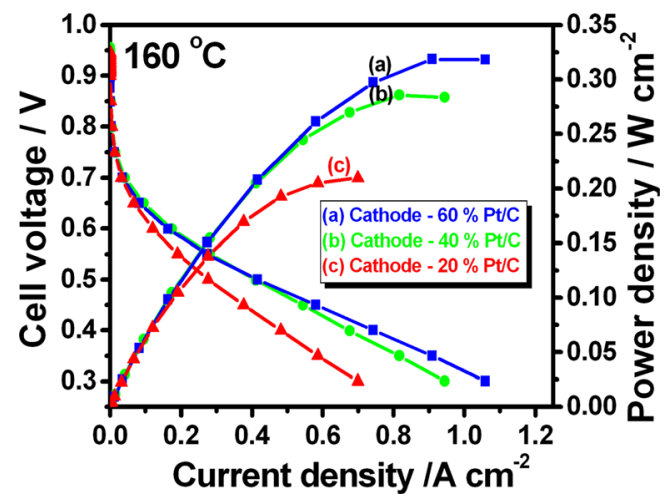

Fig 7 Fuel cell performance of ABPBI-based MEAs with GDEs of the same PTFE content but different cathode catalyst of (a) $60 \% \mathrm{Pt} / \mathrm{C},(b)$ $40 \% \mathrm{Pt} / \mathrm{C}$ and (c) $20 \% \mathrm{Pt} / \mathrm{C}$ catalysts $\left(1.0 \mathrm{mg} \mathrm{Pt} \mathrm{cm}{ }^{-2}, 40 \% \mathrm{PTFE}\right.$, $20 \mathrm{mg} \mathrm{H}_{3} \mathrm{PO}_{4} \mathrm{~cm}^{-2}$ per electrode) 
Effect of Electrocatalyst Support on Fuel Cell Performance

Replacement of conventional electrocatalysts support (Vulcan XC-72 supported Pt catalysts) by high surface area carbon supported Pt catalysts on fuel cell performance was investigated. HSAC black supported catalysts show smaller particle size which increases the active Pt surface area. The influence on the carbon support with different surface area on the fuel cell performance at $160^{\circ} \mathrm{C}$ was studied. Conventional Vulcan carbon (JM HiSPEC ${ }^{\circledR}$ 9000) (surface area $=$ ca. $250 \mathrm{~m}^{2} \mathrm{~g}^{-1}$ ), and high surface area advanced carbon support (JM HiSPEC ${ }^{\circledR}$ 9100) (surface area $=c a .800 \mathrm{~m}^{2} \mathrm{~g}$ ) was used as cathode electrocatalyst support $[24,25]$. The weight ratio of $\mathrm{Pt} / \mathrm{C}$ was around $60 \%$ in both catalysts. The fuel cell performance is commonly influenced by the morphology, hydrophobic properties, density and surface area of the carbon support [21].

The BET surface areas and pore volumes of $60 \% \mathrm{Pt} / \mathrm{C}$ and $60 \% \mathrm{Pt} / \mathrm{HSAC}$ catalysts are summarized in Table 1 . As expected, the BET surface area and the pore volume values for the catalyst with $60 \% \mathrm{Pt}$ on high surface area carbon are higher than those for the catalyst containing $60 \% \mathrm{Pt}$ on Vulcan carbon support. The comparison of fuel cell performances of $60 \% \mathrm{Pt} / \mathrm{C}$ and $60 \% \mathrm{Pt} / \mathrm{HSAC}$ (JM HiSPEC ${ }^{\circledR}$ 9100) catalyst are shown in Figure 8. HSAC catalyst support outperforms at lower current density than that of the Vulcan carbon support. The overall fuel cell performance of $60 \% \mathrm{Pt} /$ HSAC is lower than that of $60 \% \mathrm{Pt} / \mathrm{C}$.

Sixty percent platinum supported on low pore volume Vulcan carbon $(60 \% \mathrm{Pt} / \mathrm{C})$ presents the highest Pt particle size of $5.4 \mathrm{~nm}$, whereas using the HSAC support with the high pore volume leads to a considerable decrease in particle size to $3.5 \mathrm{~nm}$. Even though the Pt particle size is smaller for the $60 \%$ $\mathrm{Pt} / \mathrm{HSAC}$ catalyst compared to $60 \% \mathrm{Pt} / \mathrm{C}$ catalysts, the performance of $\mathrm{Pt} / \mathrm{HSAC}$ catalyst is poor in the kinetic region [22]. High surface area advanced carbon is made of many micropores than mesopores, and the lower fuel cell performance of high surface area advanced carbon support is due to Pt particles mainly distributed in the micropores affecting the

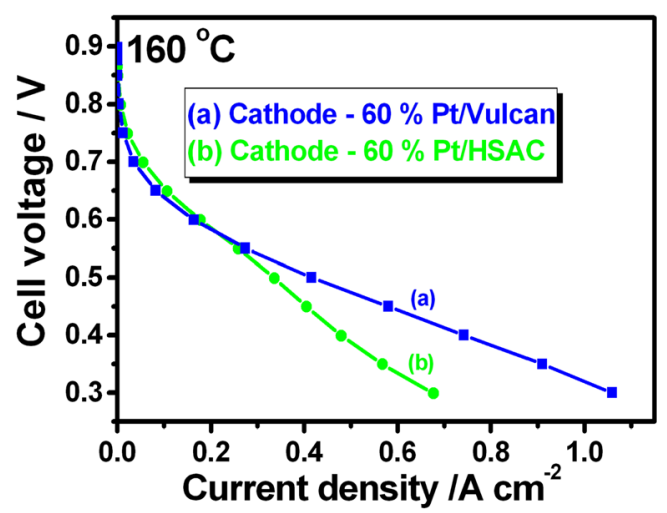

Fig 8 Fuel cell performance of ABPBI-based MEAs with different carbon support of (a) $60 \% \mathrm{Pt} / \mathrm{Vulcan}$ and $(b) 60 \% \mathrm{Pt} / \mathrm{HSAC}$ catalysts (1.0 mg Pt cm ${ }^{-2}, 40 \%$ PTFE, $20 \mathrm{mg} \mathrm{H}_{3} \mathrm{PO}_{4} \mathrm{~cm}^{-2}$ per electrode) access to the reactants on them. The other possible explanation was given by Mamouk et al. [26], i.e. (1) HSAC is more hydrophobic than Vulcan carbon, which leads to lower content of phosphoric acid in the catalyst layer, and (2) HSAC carbon has lower density which forms thicker catalyst layers than Vulcan carbon which hinders the mass transport of the reactants. Lower fuel cell performance for $60 \% \mathrm{Pt} / \mathrm{HSAC}$ than $60 \% \mathrm{Pt} / \mathrm{C}$ for PBI-based high-temperature MEAs has been reported [26].

Effect of Carbon Monoxide Tolerance on Anode Performance of ABPBI-Based MEAs at various temperatures

In 'real' fuel cell conditions, the fuel cell system will often run on a hydrogen-rich gas made from reformed fuels. The reformate gas will contain some reasonable percentage of carbon monoxide. Carbon monoxide poisons the platinum catalytic sites, and as the temperature rises, Pt tolerance to carbon monoxide poisoning increases. HT-PEM fuel cells are highly tolerant of $\mathrm{CO}$ poisoning. HT-PEM fuel cells show more than 100 times carbon monoxide (CO) tolerance in comparison to low-temperature PEM fuel cells [27-30]. The influence of CO on the performance of HT-PEMFC using various $\mathrm{CO}$ concentrations at $160{ }^{\circ} \mathrm{C}$ is shown in Figure 9. The anode exhibited a high tolerance to impurities in the gas fed at $160{ }^{\circ} \mathrm{C}$. The increase in $\mathrm{CO}$ tolerance increases with fuel cell operating temperature, and as expected, at $180{ }^{\circ} \mathrm{C}, \mathrm{CO}$ tolerance is higher than at $120^{\circ} \mathrm{C}$.

There is no significant loss in fuel cell performance when a mixture of $\mathrm{H}_{2}$ and $\mathrm{CO}(0.05 \%)$ was used as a fuel feed at $160{ }^{\circ} \mathrm{C}$. The cell showed capable tolerance to $1 \%$ vol. $\mathrm{CO}$ with current densities above $620 \mathrm{~mA} \mathrm{~cm}^{-2}$. However, similar fuel cells performance loss has been reported with $1.0 \% \mathrm{CO}$ at $150{ }^{\circ} \mathrm{C}$ for the PBI and ABPBI membrane based fuel cells $[31,32]$. In agreement with other authors, the $\mathrm{CO}$ tolerance can be further improved by humidification in $\mathrm{CO}$ and $\mathrm{H}_{2}$ mixtures. It was reported that the presence of water vapour

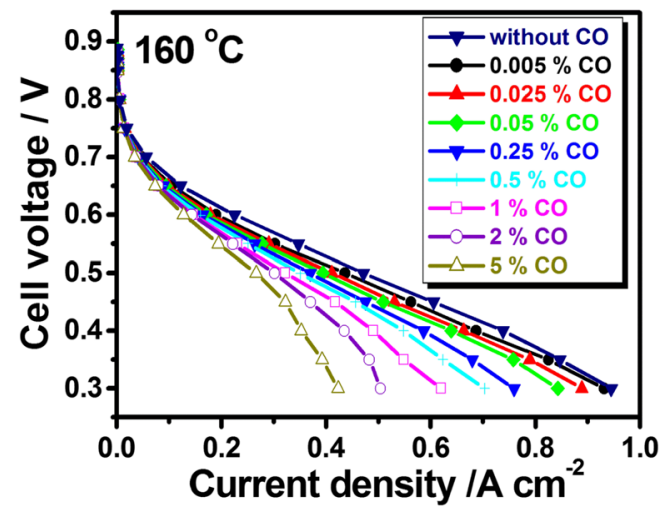

Fig 9 Fuel cell performance of ABPBI-based MEAs at $160{ }^{\circ} \mathrm{C}$ using different $\mathrm{CO}$ concentrations with hydrogen with same GDEs composition (40\% Pt/C, $1.0 \mathrm{mg} \mathrm{Pt} \mathrm{cm}{ }^{-2}, 40 \%$ PTFE, $20 \mathrm{mg} \mathrm{H}_{3} \mathrm{PO}_{4} \mathrm{~cm}^{-2}$ per electrode) 
in the $\mathrm{H}_{2}+\mathrm{CO}$ mixture decreases the $\mathrm{CO}$ partial pressure and favours $\mathrm{OH}$ adsorption on Pt sites. Enhanced $\mathrm{CO}$ tolerance of Pt catalysts by gas humidification suggests that the removal of adsorbed $\mathrm{CO}$ by the well-known 'bifunctional mechanism' $[30,33]$.

Effect of Pt Alloy catalysts on Cathode Performance ABPBI MEAs

It is usually desirable to alloy platinum with transition metals that are considerably more active for ORR activity over pure $\mathrm{Pt} / \mathrm{C}$ [34]. Mukerjee et al. investigated the electrochemical performances of various Pt bimetallic alloys supported on carbon in low-temperature fuel cells and found a threefold increase in the performance for the alloy catalysts [35]. Alloying inhibits the formation of Pt-OH intermediates, which are considered to block the active Pt site for ORR [36]. Pt alloys' cathode catalysts studied in this work are $20 \% \mathrm{Pt} / \mathrm{C}$, $20 \% \mathrm{Pt}-\mathrm{Fe} / \mathrm{C}, 20 \% \mathrm{Pt}-\mathrm{Ni} / \mathrm{C}$ and $20 \% \mathrm{Pt}-\mathrm{Cu} / \mathrm{C}$ (E-TEK, USA). All the studied alloy catalysts had atomic ratios of $(1: 1 \mathrm{a} / \mathrm{o})$. The platinum loading for the alloy catalyst was kept

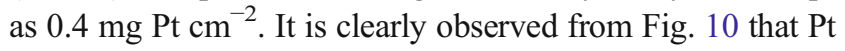
alloy catalysts show better electrochemical performances at all temperatures $\left(140,160\right.$ and $\left.180{ }^{\circ} \mathrm{C}\right)$ than $\mathrm{Pt} / \mathrm{C}$ catalysts. At low temperature $\left(140^{\circ} \mathrm{C}\right)$, the fuel cell performance of Pt-Fe catalysts performs better at higher current density than $\mathrm{Pt}-\mathrm{Ni} / \mathrm{C}$ catalysts and at low current density $\left(0.4 \mathrm{~A} / \mathrm{cm}^{2}\right)$, both Pt-Fe and Pt-Ni give similar performances. The electrochemical stability of $\mathrm{Pt}-\mathrm{Ni} / \mathrm{C}$ is less than the $\mathrm{Pt} / \mathrm{C}$ catalyst, and the catalyst degradation is due to $\mathrm{Ni}$ dissolution from a Pt-Ni/C catalyst [37]. At a low temperature of $140{ }^{\circ} \mathrm{C}, \mathrm{Pt}$ and Pt-Fe/C shows a similar performance at higher current density; however, at a higher temperature $\left(180^{\circ} \mathrm{C}\right), \mathrm{Pt}-\mathrm{Fe} / \mathrm{C}$ performs better than $\mathrm{Pt} / \mathrm{C}$. The data confirms the reported advantage of $\mathrm{Pt}$ alloying (with iron) increases ORR kinetics at higher temperatures [38]. Interestingly, Pt-Cu/C significantly outperforms the all Pt alloy catalysts at all temperatures.

The fuel cell performance of the catalysts decreased in the order of Pt-Cu/C $>$ Pt-Fe $/ \mathrm{C}>\mathrm{Pt}-\mathrm{Ni} / \mathrm{C}>\mathrm{Pt} / \mathrm{C}$. Pt-Cu/C alloy turned out to be the best catalyst showing higher activity compared to pure Pt towards oxygen reduction for low-temperature PEMFCs [39, 40]. Our recent study shows that $\mathrm{Pt}-\mathrm{Cu}$ catalysts exhibits higher ORR activity than all Pt alloy catalysts under half cell conditions [41]. The enhanced electrochemical performance of Pt-Cu catalysts is due to the modified electronic properties of surface $\mathrm{Pt}$ atoms and weakening of Pt-O bond. Under identical conditions, at $160{ }^{\circ} \mathrm{C} \mathrm{Pt}-\mathrm{Cu} / \mathrm{C}$ exhibited a better electrochemical performance than the $\mathrm{Pt} / \mathrm{C}$, with a current density $\left(1420 \mathrm{~mA} \mathrm{~cm} \mathrm{mg}^{-1} \mathrm{Pt}\right)$ i.e. ca. 1.5 times higher than that of the $\mathrm{Pt} / \mathrm{C}\left(1000 \mathrm{~mA} \mathrm{~cm}^{-2} \mathrm{mg}^{-1} \mathrm{Pt}\right)$ which proved that the $\mathrm{Pt}-\mathrm{Cu} / \mathrm{C}$ catalysts are potentially better catalysts than other Pt alloys in a practical environment [42].
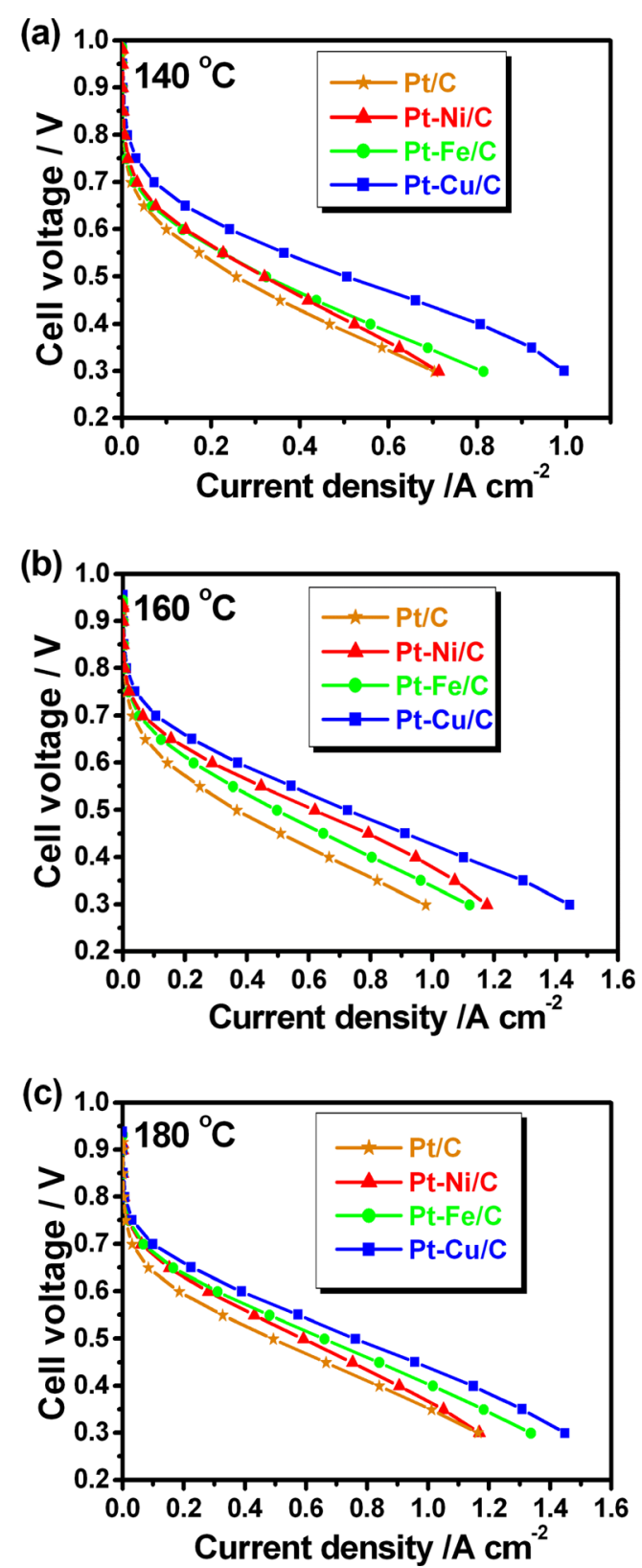

Fig 10 Fuel cell performance of ABPBI-based MEAs using different $\mathrm{Pt}$ alloy cathode catalysts $(20 \% \mathrm{Pt} / \mathrm{C}, 20 \% \mathrm{Pt}-\mathrm{Ni} / \mathrm{C}, 20 \% \mathrm{Pt}-\mathrm{Fe} / \mathrm{C}$ and $20 \%$ $\mathrm{Pt}-\mathrm{Cu} / \mathrm{C})$ at a $140{ }^{\circ} \mathrm{C}, \mathbf{b} 160{ }^{\circ} \mathrm{C}$ and $\mathbf{c} 180{ }^{\circ} \mathrm{C}$ with same GDEs composition ( $40 \%$ PTFE, $20 \mathrm{mg} \mathrm{H}_{3} \mathrm{PO}_{4} \mathrm{~cm}^{-2}$ per electrode, $0.4 \mathrm{mg} \mathrm{Pt} \mathrm{cm}{ }^{-2}$ )

\section{Conclusion}

The phosphoric acid doped ABPBI membrane fuel cell performance is significantly affected by various electrode parameters, such as cathode catalyst loading, heat treatment effects, PTFE content and electrocatalyst support. The electrodes with different platinum percentages on the carbon support $(20,40$ and $60 \%$ ) with constant $\mathrm{Pt}$ loading of $1 \mathrm{mg} \mathrm{cm}^{-2}$ were physiochemically characterized and their fuel cell performances were evaluated. Among the $\mathrm{Pt}$ alloy catalysts studied, $\mathrm{Pt}-\mathrm{Cu} / \mathrm{C}$ catalysts show superior performance with similar metal loading. 
The results of ABPBI-based MEAs with optimized electrode parameters show higher fuel cell performance and $\mathrm{CO}$ tolerance and have a great potential for commercialization, especially for stationary CHP applications. Therefore, further extensive research on this material and electrode is required, with particular emphasis on stability over a long lifetime.

Acknowledgments This work was supported by the Hydrogen and Fuel Cell Technologies RDI Programme (HySA) funded by the Department of Science and Technology in South Africa (project KP1-S01).

\section{References}

1. T. Maiyalagan, P. Sivakumar, Mater Sci Forum 657, 143 (2010)

2. S.-K. Kim, T. Ko, S.-W. Choi, J.O. Park, K.-H. Kim, C. Pak, H. Chang, J.-C. Lee, J Mater Chem 22, 7194 (2012)

3. K. A Mauritz and R. B Moore, Chem. Rev.104, 4535 (2004)

4. A. Hawkes, I. Staffell, D. Brett, N. Brandon, Energy Environ Sci 2, 729 (2009)

5. A. Yamamoto, Fuel Cell Seminar \& Exposition (Phoenix, Arizona, 2008)

6. K.T. Adjemian, S.J. Lee, S. Srinivasan, J. Benziger and A.B... Bocarsly, J. Electrochem. Soc.149 A256 (2002)

7. J.S. Wainright, J.T. Wang, R.F. Savinell and M.H. Litt, J. Electrochem. Soc.,142, L121 (1995)

8. D. Weng, J.S. Wainright, U. Landau and R.F. Savinell, J. Electrochem. Soc.,143, 1260 (1996)

9. C. Wannek, B. Kohnen, H.-F. Oetjen, H. Lippert, J. Mergel, Fuel Cells 8, 87 (2008)

10. L-A. Diaz, G-C. Abuin and H-R. Corti, J. Power Sources, 188, 45 (2009)

11. H. Zhang, P.K. Shen, Chem Rev 112, 2780 (2012)

12. T.J. Schmidt, J. Baurmeister, J Power Sources 176, 428 (2008)

13. 13.A.D. Modestov, M.R. Tarasevich, V.Ya. Filimonov and N.M. Zagudaeva, Electrochim. Acta, 4, 7121 (2009)

14. S. Litster, G. McLean, J Power Sources 130, 61 (2004)

15. M. Prasanna, H.Y. Ha, E.A. Cho, S.A. Hong, I.H. Oh, J Power Sources 131, 147 (2004)

16. J. Lobato, P. Canizares, M.A. Rodrigo, J.J. Linares, D. Ubeda, F.J. Pinar Fuel Cells, 10, 312 (2009)

17. C. Wannek, I. Konradi, J. Mergel, W. Lehnert, Int J Hydrogen Energy 34, 9479 (2009)
18. C. Wannek, W. Lehnert, J. Mergel, J Power Sources 192, 2589 (2009)

19. E. Antolini Appl. Cat.B: Environ. 88, 1 (2009)

20. L. Giorgi, E. Antolini, A. Pozio, E. Passalacqua, Electrochim Acta 43, 3675 (1998)

21. G. Velayutham, J. Kaushik, N. Rajalakshmi, K.S. Dhathathreyan, Fuel Cells 7, 314 (2007)

22. 22.K. E. Gubbins and R. D. Walker, J. Electrochem. Soc.112, 469 (1965)

23. F. Gan, D.-T. Chin, J Appl Electrochem 23, 452 (1993)

24. Safety data sheet of Vulcan XC-72 R, Cabot Corporation, France (2007) www.cabot-corp.com

25. T. Maiyalagan, A. Nassr, T.O Alaje, M.Bron, K. Scott, J Power Sources 211, 147 (2012)

26. M. Mamouk, K. Scott, J Power Sources 35, 784 (2010)

27. Q. Li, R. He, J.A. Gao, J.O. Jensen, N.J. Bjerrum, J Electrochem Soc 150, A1599 (2003)

28. K. Kwon, D.Y. Yoo, J.O. Park, J Power Sources 185, 202 (2008)

29. A.R. Korsgaard, R. Refshauge, M.P. Nielsen, M. Bang, S.K. Kaer, J Power Sources 162, 239 (2006)

30. A.D. Modestov, M.R. Tarasevich, V.Ya. Filimonov and E.S. Davydov, Electrochim. Acta, 55, 6073 (2010)

31. P. Krishnan, J.-S. Park and C.-. Kim, J. Power Sources, 159, 817 (2006)

32. M. Mamouk, K. Scott, Int J Energy Res 35, 507 (2011)

33. R. Jiang, K.H. Russell, J.M. Fenton, Electrochim Acta 51, 5596 (2006)

34. H.A. Gasteiger, S.S. Kocha, B. Sompall, F.T. Wagner, Appl Catal B Environ 56, 9 (2005)

35. S. Mukerjee, S. Srinivasan, M.P. Soriaga, J. Mcbreen, J Electrochem Soc 142, 1409 (1995)

36. P. Strasser, S. Koh, T. Anniyev, J. Greeley, K. More, C.F. Yu, Z.C. Liu, S. Kaya, D. Nordlund, H. Ogasawara, M.F. Toney, A. Nilsson, Nat Chem 2, 454 (2010)

37. Y.-H. Cho, T.-Y. Jeon, S.J. Yoo, K.-S. Lee, M. Ahn, O.-H. Kim, Y.-H. Cho, J.W. Lim, N. Jung, W.-S. Yoon, H. Choe, Y.-E. Sung, Electrochim Acta 2012(59), 264 (2012)

38. M. Mamouk, K. Scott, J Power Sources 196, 1084 (2011)

39. P. Mani, R. Srivastava, P. Strasser, J Phys Chem C 112, 2770 (2008)

40. G. Gupta, D. Slanac, P. Kumar, J.D. Wiggins-Camacho, X. Wang, S. Swinnea, K.L. More, S. Dai, K.J. Stevenson, K.P. Johnston, Chem Mater 2009(21), 4515 (2009)

41. A.N. Valisi, T. Maiyalagan, L. Khotseng, V. Linkov, S. Pasupathi, Electrocatalysis 3, 108 (2013)

42. M.Wang, W. Zhang, J.Wang, A. Minett, V. Lob, H. Liu and J. Chen, J. Mater. Chem. A,1, 2391 (2013) 